\title{
A CHRONOLOGICAL LIST OF REFERENCES ON SWITCHED CAPACITOR CIRCUITS ${ }^{\dagger}$
}

\author{
J. VANDEWALLE \\ Departement Elektrotechniek - E.S.A.T. Laboratory, Kardinaal Mercierlaan 94, \\ B-3030 Heverlee, Belgium \\ ${ }^{\dagger}$ Paper originally presented at the Summer Course on Switched Capacitor Circuits held at the Catholic \\ University of Leuven, Heverlee, Belgium, 9-12 June, 1981.
}

(Received October 11,1981)

\begin{abstract}
A chronological list of 440 references on switched capacitor circuits is compiled. Such circuits have cut the cost of filters and signal processing devices for telecommunications, speech and consumer products because they can be easily integrated on a chip. The bibliography shows the explosion of interest since 1977 by IC designers, CAD developers and circuit and filter theorists and practitioners alike.

Very specialized publications as well as elementary papers and books have been included.
\end{abstract}

\section{INTRODUCTION}

The ability to combine analog (capacitors and op amps) and digital (switches) components on one chip first made it possible around 1977 to make a filter on a chip. Many design procedures have been developed, some based on LC structures, wave concepts and active filter techniques. Moreover many approximate or computer aided analysis techniques have been developed in order to analyze the frequency, noise and sensitivity characteristics and to simulate several peculiar effects, such as aliasing, parasitic stray capacitances, offset, drift, op amp poles, switch resistances and nonlinearities. Most importantly, because of the low cost these circuits have already been implemented in a wide variety of signal processing applications such as telecommunications, speech analysis and synthesis and consumer products; and many more applications are expected to come. Hence this whole area has received much attention from IC designers, CAD developers, and circuits and filtertheorists and practitioners alike.

This has motivated us to organize in our laboratory a summer course on this subject for which we compiled the bibliography. It is based on the references of the speakers, many references in papers, and the historical survey of Fettweis (1981) and the survey of Japanese contributions (Suzuki e.a. 1981).

Included are all the conference and journal papers and books which we were able to receive and which deal with general background results and specific topics of IC implementation, design, analysis, simulation or applications. This list ends on May 1981. The explosion of interest is quite evident by looking at the plot of the number of publications in each year (Figure 1).

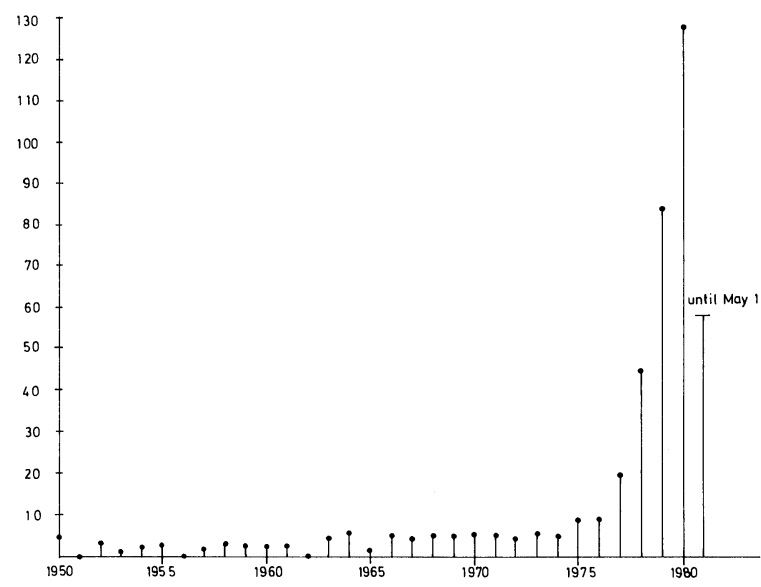

FIGURE 1 Number of publications on switched capacitor circuits from 1950 to 1981 .

\section{REFERENCES}

1939

R.S. Caruthers, "Copper oxide modulators in carrier telephone systems", Bell. Syst. Techn. J., 18, pp. 315-337, April 1939.

1948

V. Belvitch, "Linear theory of bridge and ring modulator circuits", Electr. Comm., 25, pp. 162-173, March 1948.

O. Henkler, Anwendungen der Modulation beim Traegerfrequenz fernsprechen, S. Hirzel, Leipzig, 1948. 
1950

L.A. Zadeh, "Frequency analysis of variable networks", Proc. IRE, 38, pp. 291-299, March 1950.

L. Zadeh, "Circuit analysis of linear varying-parameter networks", J. Appl. Phys. 21, No. 11, 1950.

1952

H.B. Haard and C.G. Svala, U.S. Patent No. 2718621, 1953, first filed in Sweden, March 12, 1952.

W.R. Le Page, C.R. Cahn and J.S. Brown, "Analysis of a comb filter using synchronously commutated capacitors", AIEE Trans. Comm. and Electronics, 72, pp. 63-68, March 1952.

J.R. Ragazzini and L.A. Zadeh, "The analysis of pulse systems", Trans. AIEE, 71, part II, 1952.

\section{3}

D.G. Tucker, Modulators and Frequency Changers, Macdonald, London, 1953.

1954

K.W. Cattermole, British Patent No. 753 645, first filed: 3 Dec. 1954.

L.A. Pipes, "Matrix analysis of linear time varying circuits", J. Appl. Phys., 25, pp. 1179-1185, 1954.

1955

W.R. Bennett, "Steady state transmission through networks with containing periodically operated switches", IRE Trans. Circuit Theory, CT-2, pp. 17-21, 1955.

A. Fettweis, "Steady state analysis of circuits containing a periodically operated switch", IRE Trans. Circuit Theory, CT-1, pp. 17-21, 1955.

J.A. French, British Patent No. 841 555, first filed: 14 April 1955.

1957

C.A. Desoer, "A network containing a periodically operated switch solved by successive approximations", BSTJ, 36, pp. 1403-1428, 1957.

W.D. Lewis, "Switching Circuit", US Patent No. 2936 337, first filed: 9 Jan. 1957.

1958

K.W. Cattermole, "Efficiency and reciprocity in pulse amplitude modulation", Proc. IEE, 105, Pt. B, pp. 449-462, 1958.

C.A. Desoer, "Transmission through a linear network containing periodically operated switches", in 1958 WESCON Rec., Pt. 2, pp. 34-41.

E.I. Jury, Sampled-Data Control Systems, Wiley New York, 1958.

V.A. Taft, Elektricheskiye tsepi s periodicheski izmenyay. ushchimisya parametrami i perekhodnyye protsessy $v$ sinkhronnykh mashinakh (Electrical circuits with periodically varying parameters and transient processes in synchronous machines), Izd., Akad. Nauk SSSR, 1958.
1959

V. Belevitch, Theorie des circuits non-lineaires en regime alternatif, Uystpruyst, Louvain, 1959.

C.A. Desoer, "Steady state transmission through a network containing a single time-variant element", IRE Trans. Circuit Theory, pp. 249-252, Sept. 1959.

V.A. Taft, "On the analysis of stability of periodic modes of operation in non-linear automatic-control systems, Avtomat. i telemekh., No. 9, 1959.

1960

A. Fettweis, "Filters met willekeurig gekozen dempingspolen en Tschebyschewkarakteristiek in het doorlaatgebied", Section 8, Tijdschrift van het Nederlands Radiogenootschap (Netherlands), 25, No. 5-6, pp. 337-382, 1960.

A. Fettweis, "Steady state analysis of circuits containing a periodically operated switch", IRE Trans. Circuit Theory, CT-6, pp. 252-260, Sept. 1960.

L.E. Franks and I.W. Sandberg, "An alternative approach to the realization of network transfer functions: the N-path filter", Bell. Syst. Techn. J., pp. 1321-1350, Sept. 1960.

1961

B.U. Kinarawala, "Analysis of time variant networks", Inst. Radio Engineers, Int. Convention Rec., p. 4, pp. 268-276, 1961.

G. Wunsch, "The mathematical analysis of linear systems with time variant parameters", Nachrichtentechnik II (in German), pp. 221-232, May 1961.

L.A. Zadeh, "Time-varying networks", Proc. IRE, pp 1488-1503, Oct. 1961.

1963

C. Kurth, "Die Anwendung digitaler Rechenanlagen bei der Analyse und Berechnung von Frequenzumsetzern mit reaktiven Ein- und Ausgangsnetzwerken", Arch. Elek. Uebertr., 17, pp. 325-337, July 1963.

A. Fettweis, "Theorie des circuits a transfert resonnant", Doctoral dissertation, University of Louvain, Belgium, 1963.

C.F. Kurth, "Poles and zeros in time-variant networks", (in German), $A E U E, 17$, pp. 547-563, Dec. 1963.

C.F. Kurth, "The analysis of quasilinear frequency modulations with selective terminations", $A E U E$ (in German), 17, pp. 325-337, Aug. 1963.

C. Kurth, "Die Analyse von zeitvariablen Netzwerken unter Verwendung einer Spektralmatrix im Frequenzbereich", Arch. Elektr. Uebertr., 17, pp. 237-248, May 1963 and p. 337, July 1963 .

1964

E.I. Jury, Theory and Application of the z-Transform Method, John Wiley and Sons, New York, 1964.

C.F. Kurth, "Spectral matrix for the analysis of timevariant networks", Elec. Commun., 39, No. 2, pp. 277-292, 1964. 
I.W. Sandberg, "On truncation techniques in the approximate analysis of periodically time varying nonlinear networks", IEEE Trans. Circuit Theory, CT-11, pp. 195-201, June 1964.

M. Schlichte, German Patent No. 1135 972, first filed: 20 Dec. 1964.

V.A. Taft, Electrical Circuits with Variable Parameters including Pulsed Control Systems, Pergamon, Oxford, 1964 (translation from Russian).

D.G. Tucker, Circuits with Periodically Varying Parameters, D. Van Nostrand, New York, 1964.

\section{5}

G. Schweizer, "A general method for the analysis of systems with time variant coefficients", $A E U E$ (in German), 19, pp. 469-482, Sept. 1965.

\section{6}

M.P. Erugin, Linear Systems of Ordinary Differential Equations with Periodic and Quasi-periodic Coefficients, Academic, New York, 1966.

H.J. Orchard, "Inductorless filters", Electron. Lett. 2 , pp. 224-225, June 1966.

W. Kuntz, "Ueber Entwurf und Anwendung von AbtastFiltern", Proc. NTG-Fachtagung, "Analyse und Synthese von Netzwerken", pp. 261-277, Stuttgart (West Germany), 31 March and 1 April, 1966.

W. Poschenrieder, "Frequenzfilterung durch Netzwerke mit periodisch gesteuerten Schaltern" in Proc. NTG-Symp., "Analyse und Synthese von Netzwerken", Stuttgart, pp. 221-237, 1966.

Y. Sun, "Analysis of periodically time-varying digital filters" in Proc. 19th Midwest Symp. on Circuits Syst., pp. 109-112, Aug. 1966.

\section{7}

L. Baker, "Dynamic transfer networks", US Patent, No. 3 469 213, Sept. 23, 1969 (filed May, 1967).

E.S. Kuh and R.A. Rohrer, Theory of Linear Active Networks, Holden-Day, San Francisco, CA, ch. 10, 1967.

K. Moehrmann, K. Heinlein, "N-Pfad-Filter hoher Selektivitaet mit spulenlosen Swingkreisen", Frequenz, pp. 369-375, Dec. 1967.

Y. Sun and I.T. Frisch, "Transfer functions and stability for networks with periodically varying switches", in Proc. 1st. Asilomar Conf. Circuits and Systems, pp. 130-142, Nov. 1967.

\section{8}

R. Boite and J.V.P. Thiran, "Synthesis of filters with capacitances, switches, and regenerating devices", IEEE Trans. Circuit Theory, CT-15, pp. 447-454, Dec. 1968.

A. Fettweis, "Theory of resonant-transfer circuits and their application to the realization of frequency-selective networks", Proc. URE, Summer School on Circuit Theory, 68 pages, Prague, July 1968.
A. Fettweis, "Theory of resonant-transfer circuits", Network and Switching Theory, G. Biorci, Ed., Academic Press, 1968, pp. 382-446.

J.A. McKinney and C.A. Halijak, "The periodically reverseswitched capacitor", IEEE Trans. Circuit Theory, CT-15, No. 3, pp. 288-290, 1968.

W. Kuntz, "A new sample-and-hold device and its application to the realization of digital filters", Proc. IEEE, 56, pp. 2092-2093, Nov. 1968.

\section{9}

S. Cantarano and G.V. Pallotino, "Approximate results for networks containing periodically operated switches", Proc. IEEE, 56, p. 2070, Nov. 1969.

A. Fettweis, "Resonant-transfer filters". Proc. Third Asilomar Conf. on Circuits and Systems, p. 309, Pacific Grove, Cal., Dec. 1969.

A. Fettweis, "Input and output networks with constant input pulse impedances for resonant-transfer circuits", Trans. IEEE, CT-16, 562-564, 1969.

L.E. Franks, Signal Theory, Prentice Hall, Englewood Cliffs, 1969.

E. Langer, Spulenlosse Hochfrequenz-filter, Entwiklungsberichte Fy Siemens, 1969.

1970

H. D'Angelo, Linear Time-Varying Systems: Analysis and Synthesis, Allyn and Bacon, Boston, 1970.

A. Fettweis, "Some properties of pulse impedances and pulse impedance matrices", Arch. Elektr. Uebertrag., 24, pp. 506-512, Nov. 1970.

A. Fettweis, "On the theory of periodically reverse-switched capacitor networks", Arch. Elek. Ubertragung, 24, No. 12, pp. 539-544, Dec. 1970.

F.E.J. Girling and E.F. Good, "Active filters 12: The leap frog or active ladder synthesis", Wireless World, 76, pp. 341-345, July 1970 .

A.G.J. Holt and C. Pule, "Relation of resampled switched sampled analogue filters to digital filters", Int. J. Electron., 28, No. 4, pp. 331-340, 1970.

1971

R. Boite, "Discrete-time systems with interwoven transfers". Proc. IEE, 118, pp. 312-316, 1971.

A. Fettweis, "Digital filter structures related to classical filter networks", Arch. Elektr. Uebertr., 25, pp. 79-89, Feb. 1971.

A. Fettweis, "Realization of general network functions using the resonant-transfer principle" in Proc. Fourth Asilomar Conf. on Circuits and Systems, pp. 663-666, 671 (Pacific Grove, CA), Nov. 1970, also Arch. Elektr. Uebertr. 25, pp. 295-303, June 1971

A. Fettweis and H. Wupper, "A solution to the balancing problem in N-path filters", IEEE Trans. Circuit Theory, CT-18, pp. 403-405, May 1971. 
A. Fettweis, "Conversion functions of circuits for recovery and sampling in PCM terminals", Arch. Elektr. Uebertr., 26, pp. 201-206, May 1972.

J. Gensel, "Asynchrone Schalternetzwerke", Nachrichtentech$n i k$, 21, pp. 425-428, Dec. 1971.

W.E. Heinlein, K.H. Moehrmann and W.H. Holmes, "Doubletuned N-path bandpass filters using a single gyrator", IEEE Trans. on Circuit Theory, pp. 728-729, Nov. 1971.

1972

D.L. Fried, "Analog sample-data filters", IEEE J. Solid State Circuits, SC-7, No. 4, pp. 302-304, Aug. 1972.

K. Hirano and S. Nishimura, "Active RC filters containing periodically operated switches", IEEE Trans. Circuit Theory, CT-19, pp. 253-260, May 1972.

M.L. Liou, "Exact analysis of linear circuits containing periodically operated switches with applications", IEEE Trans. Circuit Theory, CT-19, pp. 146-154, March 1972.

H. Weinrichter, "Kondensator-Kommutator-Netzwerke", Arch. Elektr. Uebertragung, 26, pp. 293-305, July/Aug. 1972.

1973

D.D. Buss, D.R. Collins, W.H. Bailey and C.R. Reeves, "Transversal filtering using change-transfer devices", IEEE J. Solid State Circuits, SC-8, pp. 138-146, April 1973.

L.E. Franks, "N-path filters", Modern Filter Theory and Design, G.C. Temes and S.K. Mitra, Eds., John Wiley Sons Inc., 1973.

C.B. Moler and G.W. Stewart, "An algorithm for the generalized matrix eigenvalue problem", SIAM J. Numer. Anal., 10, pp. 241-256, 1973.

R. Orfei and G.V. Pallotino, "Networks containing periodically operated switches - A State space approach", Circuit Theory and Applications, 1, pp. 373-386, 1973.

G.C. Temes and H.J. Orchard, "First-order sensitivity and worstcase analysis of doubly terminated reactance two-ports", IEEE Trans. Circuit Theory, CT-20, pp. 567-571, Sept. 1973.

1974

L. Baker and S.D. Bedrosian, "Amplification of resistance concepts in switched networks", in Proc. IEEE Int. Symp. Circuits Syst., pp. 342-346, April 1974.

P.R. Gray and R.G. Meyer, "Recent advances in monolithic operational amplifier design", IEEE Trans. Circuits Syst., CAS-21, pp. 317-327, May 1974.

W.E. Heinlich and W. Harvey Holmes, Active Filters for Integrated Circuits. Prentice-Hall, Englewood Cliffs, N.I., 1974.

V.P. Popov, "Switch-capacitance filters" (in Russian), Izvestiya Vuzov Radioelektronika 17, pp. 36-42, 1974.

K.R. Stafford, P.R. Gray and R.A. Blanchard, "A complete monolithic sample/hold amplifier", IEEE J. Solid State Circuits, SC-9, pp. 381-387, Dec. 1974.

H. Wupper, "A modified N-path filter suited for practical realization", IEEE Trans. Circ. and Syst., CAS-21, pp. 449-456, May 1974.
1975

L. Baker and S.D. Bedrosian, "RC immitances and periodically switched networks", Electron. Lett., 11, pp. 622-623, Dec. 1975

L.T. Bruton, "Low sensitivity digital ladder filters", IEEE Trans. Circuits Syst., CAS-22, No. 3, pp. 168-176, March 1975.

L.O. Chua and P.M. Lin, Computer Aided Analysis of Electronic Circuits; Algorithms and Computational Techniques, Prentice-Hall, N.J., 1975.

R.E. Crochiere and A.V. Oppenheim, "Analysis of linear digital networks", Proc. of IEEE, 63, No. 4, pp. 581-595, April 1975.

G.P. Edwards et al., "A MOS LSI double second-order digital filter circuit", ISSCC Digest of Technical Papers, pp. 20-21, Feb. 1975.

C.W. Ho, A.E. Ruehli and P.A. Brennan, "The modified nodal approach to network analysis", IEEE Trans. Circuits Syst., CAS-22, pp. 504-509, June 1975.

J.L. McCreary and P.R. Gray, "All-MOS charge redistribution analog-to-digital conversion techniques - Part 1", IEEE J. Solid State Circuits, SC-10, pp. 371-379, Dec. 1975.

S.I. Miroshnickenko, "Characteristics of capacitance-switch networks consisting of simultaneously switched two-poles" (in Russian), Izvestiya Vuzov Radioelektronika, 18, pp. 114-117, 1975.

R.E. Suarez, P.R. Gray and D.A. Hodges, "All-MOS charge redistribution analog-to-digital conversion techniques Part 2", IEEE J. Solid State Circuits, SC-10, No. 6 , pp. 379-385, Dec. 1975.

\section{6}

I.F. Albarran and D.A. Hodges, "A charge-transfer multiplying digital-to-analog converter", IEEE J. Solid State Circuits, SC-11, pp. 772-779, Dec. 1976.

P.O. Brackett and A. Sedra, "Direct SFG simulation of LC ladder networks, with applications to active filter design", IEEE Trans. Circuits and Systems, CAS-23, pp. 61-67, Feb. 1976

A.G.F. Dingwall and B.D. Rosenthall, "Low-power monolithic COS/MOS dual-slope 11 bit A/D converters", Digest of Technical Papers, 1976 International Solid State Circuits Conference, Philadelphia, Pennsylvania, February 1976.

A.R. Hamade and E. Campbell, "A single chip 8-bit A/D converter", ISSCC Dig. Tech. Papers, pp. 154-155, Feb. 1976.

L.G. Heller et al., "High sensitivity charge-transfer sense amplifier", IEEE J. Solid State Circuits, SC-11, pp. 596-601, Oct. 1976.

F.H. Musa and R.C. Huntington, "A CMOS monolithic 3 1/2 digit A/D converter", ISSCC Dig. Tech. Papers, pp. 144-145, 1976.

G. Smarandoiu, D.A. Hodges, P.R. Gray and K. Fukahori, "An all-MOS analog-to-digital converter using a constant slope approach", IEEE J. Solid State Circuits, SC-11, pp. 408-410, June 1976. 
Y.P. Tsividis and P.R. Gray, "An integrated NMOS operational amplifier with internal compensation", IEEE $J$. Solid State Circuits, SC-11, No. 6, pp. 748-753, Dec. 1976.

Y.P. Tsividis, P.R. Gray, D.A. Hodges and J. Chacko Jr., "A segmented u-225 law PCM voice encoder utilizing NMOS technology", IEEE J. Solid State Circuits, Vol. SC-11, pp. 740-747, Dec. 1976.

1977

G.L. Baldwin and J.L. McCreary, "A CMOS digitallycontrolled analog attenuator for voice-band signals", Proc. IEEE Int. Symp. Circuits and Syst., pp. 519-524, 1977.

J.T. Caves, M.A. Copeland, C.F. Rahim, and S.D. Rosenbaum, "Sampled analog filtering using switched capacitors as resistor equivalents", IEEE J. Solid State Circuits, SC-12, pp. 592-599, Dec. 1977.

J. Compeers and H. De Man, "Nonuniform pulse code modulation encoder using double polysilicon technology", European Solid State Circuits Conf. Dig. Tech. Papers, pp. 156-157, 1977.

J. Fellrath and E. Vittoz, "Small signal model of MOS transistors in weak inversion", Proc. Journées d'Electronique 1977, EPF-Lausanne, pp. 315-324.

A. Fettweis, "Realization of general network functions using the resonant-transfer principle", AEUE, Electron. and Commun., 25, pp. 295-303, 1977.

P.R. Gray and R.G. Meyer, Analysis and Design of Analog Integrated Circuits, Wiley, New York, 1977.

C. Hewes and M. De Wit, "NMOS Tone Generator", Proc. IEEE Int. Solid State Circuits Conference, Philadelphia, pp. 30-31, Febr. 1977.

D.A. Hodges, P.R. Gray and R.W. Brodersen, "Potential of MOS technologies for analog integrated circuits", Dig. Tech. Papers, 3rd European Solid State Circuits Conf., Ulm, pp. 43-47, Sept. 1977.

B.J. Hosticka, R.W. Brodersen and P.R. Gray, "MOS sampled data recursive filters using state variable techniques", Proc. Int. Symp. on Circuits and Systems (Phoenix, AZ), pp. 525-529, April 1977.

B.I. Hosticka, R.W. Brodersen and P.R. Gray, "MOS sampleddata recursive filters using switched capacitor integrators", IEEE J. Solid State Circuits, SC-12, pp. 600-608, Dec. 1977.

M. Koehsal and Y. Tokad, "State-space formulation of linear circuits containing periodically operated switches", Circuit Theory and Appl., 5, pp. 155-170, 1977.

C.F. Kurth, "Steady state analysis of sinusoidal time-variant networks applied to equival ent circuits for transmission networks", IEEE Trans. Circuits Syst., CAS-24, pp. 610-624, Nov. 1977.

C.F. Landsburg, "A Charge-balancing monolithic A/D converter", IEEE J, Solid State Circuits, SC-12, pp. 662-673, Dec. 1977.

R.H. McCharles, V.A. Saletore, W.C. Black, Jr. and D.A. Hodges, "An algorithmic analog-to-digital converter", Digest Tech. Papers, Int. Solid state Circuits Conf., (Philadelphia, PA, Feb. 1977), pp. 96-97.
J.L. McCreary et al., "All MOS charge redistribution analogto-digital conversion techniques - Part I", IEEE J. Solid State Circuits, SC-12, pp. 600-608, Dec. 1977.

T.W. Pickerrell and G. Grandbois, "A/D conversion techniques", Electronics, Oct. 13, 1977.

T. Strom and S. Signell, "Analysis of periodically switched linear circuits”, IEEE Trans. Circuits Syst., CAS-24, pp. 531-541, Oct. 1977.

Y.P. Tsividis, "Technique for increasing the gain-bandwidth product of NMOS and PMOS integrated inverters", Electron. Lett., 13, pp. 421-422, July 7, 1977.

E. Vittoz and J. Fellrath, "CMOS analog integrated circuits based on weak inversion operation", IEEE J. Solid State Circuits, SC-12, pp. 224-231, June 1977.

Y.S. Yee, L.G. Heller and L.M. Terman, "A $1 \mathrm{mV}$ MOS comparator", European Solid State Circuits Conf., Dig. Tech. Papers, pp. 164-166, 1977.

I.A. Young, P.R. Gray and D.A. Hodges, "Analog NMOS samplied data recursive filters", Proc. Int. Solid State Circuits Conf. (Philadelphia, PA), pp. 156-157, Feb. 1977.

1978

D.J. Allstot, R.W. Brodersen and P.R. Gray, "Consideration for the MOS implementations of switched-capacitors filters", Conf. Rec. 12th Asilomar Conf. Circuits, Systems and Computers, pp. 684-688, Nov. 1978.

D.J. Allstot, R.W. Brodersen and P.R. Gray, "Fully-Integrated high-order NMOS samples data ladder filters", ISSCC Digest of Technical Papers, pp. 82-83, Feb. 1978.

D.I. Allstot, R.W. Brodersen and P.R. Gray, "Fully-integrated high-order NMOS sampled-data ladder Filters", Int. Solid State Circuits Conf., San Francisco, CA, pp. 82-83, 268, Feb. 1978.

D.J. Allstot, R.W. Brodersen and P.R. Gray, "MOS switched capacitor ladder filters", IEEE J. Solid State Circuits, SC-13, pp. 806-814, Dec. 1978.

G. Arnout and H.J. De Man, "The use of threshold functions and Boolean controlled network elements for macro modeling of LSI circuits", IEEE J. Solid State Circuits, SC-13, pp. 326-332, June 1978.

G. Arnout et al., "The use of Boolean controlled elements for macro modelling of digital circuits", in Proc. 1978 Int. Symp. Circuits Syst., pp. 522-526, May 1978.

F. Brglez, "Exact nodal analysis of switched-capacitor networks with arbitrary switching sequences and general inputs Part I", IEEE Proc. of 12th Asilomar Conference on Circuits, Systems and Computers, Pacific Grove, Calif., pp. 679-683, Nov. 6-8, 1978.

R.W. Brodersen, P.R. Gray and D.A. Hodges, "MOS switchedcapacitor filters", Proc. of the IEEE, 67, pp. 61-75, Jan. 1978.

R.W. Brodersen, P.R. Gray, D.A. Hodges, D. Allstot and G. Jacobs, "Switched-capacitor filters for telecommunications application", 1978 European Conf. on Circuit Theory and Design, 1, pp. 228-237.

M.J. Callahan and H.L. Davis, "An integrated dual-tone multifrequency decoder”, ISSCC Dig. Papers, 1978. 
J.T. Caves, C.H. Chan, S.D. Rosenbaum, L. Sellars, and J.B. Terry, "A PCM voice codec with on-chip filters", IEEE Int. Solid State Circuits Conf. Dig. Tech. Papers, pp. 182-183, 276, Feb. 1978.

J.B. Cecil, E.M. Chow, J.A. Flink, J.E. Solomon, C.G. Svala and J. Svenson, "A two chip PCM CODEC for per channel applications", ISSCC Dig. Tech. Papers, pp. 176-177, Feb. 1978.

M.A. Copeland, "Some aspects of sampled analog MOS LSI circuits for communications", IEEE Proc. Int. Commun. Conf., 1978.

J. Fellrath, "Shot noise behaviour of subthreshold MOS transistors", Rev. de Physique Appliquée, 13, pp. 719-723, Dec. 1978.

D.L. Fraser, Jr. and A.J. Vera, "Design tools for switched capacitor filters", 1978 IEEE CCD Signal Processing Workshop, New York, May 1978.

R. Gregorian and W.E. Nicholson, Jr., "A high-pass switched capacitor filter", Conf. Rec. 12th Asilomar Conf. Circuits, Systems and Computers, pp. 669-673, Nov. 1978.

A.R. Hamade, "A single chip all-MOS 8-bit A/D converter", IEEE J. Solid-State Circuits, SC-13, pp. 785-791, Dec. 1978.

J.L. Henry and B.A. Wooley, "An integrated PCM encoder using interpolation" IEEE Int. Solid State Circuits Conf. Dig. Tech. Papers, pp. 184-185, 277, Feb. 1978.

D.A. Hodges, P.R. Gray and R.W. Brodersen, "Potential of MOS technologies for analog integrated circuits", IEEE $J$. Solid State Circuits, SC-13, pp. 285-294, June 1978.

B.J. Hosticka and G.S. Moschytz, "Switched-capacitor simulation of grounded inductors and gyrators", Electron. Lett., 14, pp. 788-790, Nov. 1978.

J.M. Huggins, M.E. Hoff and B.M. Warren, "A single-chip NMOS PCM codec for voice", ISSCC Dig. Tech. Papers, pp. 178-179, Feb. 1978 .

G.M. Jacobs, D.J. Allstot, R.W. Brodersen and P.R. Gray, "Design considerations for MOS switched capacitor ladder filters", Proc. Int. Symp. on Circuits and Systems (New York), pp. 324-329, May 1978.

G.M. Jacobs, D.J. Allstot, R.W. Brodersen and P.R. Gray, "Design techniques for MOS switched-capacitor filters", IEEE Trans. Circuits Syst., CAS-25, pp. 1014-1021, Dec. 1978.

W.K. Jenkins, T.N. Trick and E. El-Masry, "New realizations for switched-capacitor filters", Record 12th Asilomar Conference on Circuits and Systems, pp. 694-698, 1978.

S. Kato, N. Ueno, S. Matsuzaki, M. Kakuishi and A. Iwata, "A survey of switched capacitor filter transmission characteristics", 1978, National Conference Record on Communication, The Institute of Electronics and Communication Engineers of Japan, No. 353, Oct. 1978 (in Japanese).

C.F. Kurth, G.S. Moschytz, "Two-port analysis of cascaded switched-capacitor networks", IEEE Proc. Intl. Symp. Circuits and Systems, New York, p. 756, May 1978.

G.F. Landsberg and G. Smarandoiu, "A two-chip CMOS codec", ISSCC Dig. Tech. Papers, pp. 180-181, Feb. 1978.
M.L. Liou and Y.L. Kuo, "Some fundamental properties of switched-capacitor circuits", Conference Record of the 12th Asilomar Conference on Circuits, Systems and Computers, Pacific Grove, CA, p. 693, 6-8 Nov., 1978.

E. Lueder and H. Lanfer, "Equivalent sampled data filter structures and some of their properties", Proc. ISCAS, pp. 752-755, 1978.

E. Lueder, "Intergrierbare Filter is VLSI-Technik", Arch. Elektr. Uebertr. 32, pp. 381-389, Oct. 1978.

G. Martinelli and M. Salerno, "Commutated-capacitor bank as a filter resonator", Electronics Letters., 14, pp. 427-428,1978.

H.I. Orchard and G.C. Temes, "Spectral analysis of switched capacitor filters designed using bilinear z-transform", Conf. Rec. 12th Asilomar Conf. on Circuits Syst. and Computers, pp. 674-678, 1978.

C.F. Rahim, M.A. Copeland and C.H. Chan, "A functional MOS circuit for achieving the bilinear transformation in switched capacitor filters", IEEE J. Solid State Circuits, SC-13, pp. 906-909, Dec. 1978.

A. Sedra and P.O. Brackett, "Filter theory and design: active and passive", Champaign, Il., Matrix, p. 575, 1978.

D. Senderowicz, D. Hodges and P.R. Gray, "High performance NMOS operational amplifier", IEEE J. Solid State Circuits, SC-13, pp. 760-766, Dec. 1978.

G. Smarandiou, D.A. Hodges, P.R. Gray and G.F. Landsburg, "CMOS pulse-code-modulation voice CODEC", IEEE J. Solid State Circuits, SC-13, pp. 504-510, Aug. 1978.

K.S. Tan and P.R. Gray, "Fully integrated analog filters using bipolar/JFET technology", IEEE J. Solid State Circuits, SC-13, pp. 814-821, Dec. 1978.

G.C. Temes, "The derivation of switched-capacitor filters from active-RC prototypes", Electron. Lett., 14, No. 12, pp. 361-362, June 8, 1978.

G.C. Temes, "Digital-filter design techniques for the synthesis of switched-capacitor active circuits", Proc. 1978 Internat. Conf. on Digital Signal Processing, Florence, Italy, Aug. 1978.

G.C. Temes, H.I. Orchard and M. Jahanbegloo, "Switched capacitor filter design using the bilinear z-transform", IEEE Trans. Circuits Syst., CAS-25, pp. 1039-1044, Dec. 1978.

G.C. Temes and I.A. Young, "An improved switched-capacitor integrator”, Electron. Lett., 14, No.9, pp. 287-288, April 27, 1978.

I. Terry et al., "A PCM voice CODEC with on-chip filters", ISSCC Dig. of Tech. Papers, pp. 182-183, Feb. 1978.

Y. Tsividis, "Switched-capacitor network analysis", Presentation at the CCD Signal Processing Workshop, New York, May 15-16, 1978.

Y. Tsividis, "Design considerations in single-channel MOS analog integrated circuits, A tutorial", IEEE J. of Solid State Circuits, SC-13, No. 3, pp. 383-391, June 1978.

K. Yakuwa, T. Kojima, M. Yanagi and K. Shirai, "Inductorless filter applications in transmission systems", Proc. European Conf. on Circuit Theory and Design, Lausanne, p. 191-197, 1978. 
I.A. Young, E.K. Simonyi, and G.C. Temes, "Switchedcapacitor filter sections implementing the bilinear transformation", Record of the 12th Asilomar Conference on Circuits and Systems, pp. 689-692, 1978.

1979

D.I. Allstot, R.W. Brodersen and P.R. Gray, "An electrically programmable analog NMOS second-order filter", Dig. Int. Solid State Circuits Conf., Philadelphia, PA, pp. 76-77, Feb. 1979.

D.J. Allstot, R.W. Brodersen, and P.R. Gray, "An electrically programmable switched capacitor filter", IEEE J. Solid State Circuits, SC-14, pp. 1034-1041, Dec. 1979.

F. Brglez, "Exact analysis of switched-capacitor network with arbitrary switching sequences and general inputs Part II", Proc. 1979 International Symposium on Circuits and Systems, Tokyo, Iapan, pp. 748-751, Iuly 1979.

R.W. Brodersen and T.C. Choi, "Comparison of switched capacitor ladder and CCD transversal filters", Proc. 5th Int. Conf. on CCD, Edinburgh, 1979.

R.W. Brodersen, P.R. Gray and D.A. Hodges, "MOS switched-capacitor filters", Proc. IEEE, 67, No. 1, pp. 61-75, Jan. 1979.

U.W. Brugger and B.J. Hosticka, "Alternative realization of switched capacitor floating inductors", Electronics Letters, 15, No. 21, pp. 698-699, 11th October 1979.

U.W. Brugger, B.I. Hosticka and G.S. Moschytz, "Switched capacitor simulation of floating inductors using gyrators", Electronics Letters, 15, No. 16, pp. 494-496, 2nd August 1979.

R.R. Buss and D.B. Cox, "Practical solid-state integrated filters", J. Audio Eng. Soc., 27, pp. 982-988, Dec. 1979.

J.T. Caves, C.H. Chan, S.D. Rosenbaum, L.P. Sellars and J.B. Terry, "A PCM voice CODEC with on chip filters", IEEE J. Solid State Circuits, SC-14, pp. 65-73, Feb. 1979.

P. Christiansen, P.I. Gebhart and G. Kohlbacher, "Integration von filtern mit linearen MOS-Schaltungen", Wiss. bes. AEG-Telefunken 52, pp. 131-138, 1979.

M.A. Copeland and J.M. Rabaey, "Dynamic amplifier for MOS technology", Electron. Lett., 15, pp. 301-302, May $10,1979$.

R. Cuppens and H. De Man, "Simulation of large on-chip capacitors and inductors", IEEE J. Solid State Circuits, SC-14, pp. 543-546, June 1979.

A.M. Davis, "Switched capacitor techniques implement effective IC filters", EDN. 24, No. 20, pp. 103-106, 5 Nov. 1979.

H. De Man, J. Rabaey and G. Arnout, "On the simulation of switched capacitor filters and convertors using the DIANA program", Proc. European Solid State Circuits Conference, Southampton, pp. 136-138, Sept. 1979.

R. Dessoulavy, A. Knob, F. Krummenacher and E. Vittoz, "A synchronous bandpass switched capacitor filter", Fifth European Solid State Circuits Conference ESSCIRC 79, Southampton, England, p. 131-133, 18-21 Sept. 1979.
A.G.F. Dingwall, "Monolithic expandable 6b $15 \mathrm{MHz}$ CMOS/SOS A/D converter", ISSCC Dig. Tech. Papers, pp. 126-127, Feb. 1979.

S.I. Dombrovskaya and S.I. Miroshnichenko, "Features of synthesis of active switch capacitance filters", Izvestiva Vuzov Radioelektronika, 22, pp. 73-79, 1979 (American translation: pp. 69-70).

A. Fettweis, "Basic principles of switched capacitor filters using voltage inverter switches", Arch. Elektr. Uebertr., 33, pp. 13-19, Jan. 1979.

A. Fettweis, "Switched-capacitor filters using voltage invertor switches further design principles", $A E U E, 33$, pp. 107-114, March 1979.

A. Fettweis, "Switched-capacitor filters using voltage inverter switches", Proc. 1979 IEEE Int. Symp. Circuits and Systems, pp. 910-913, Tokyo, Japan, July 1979.

A. Fettweis, D. Herbst and J.A. Nossek, "Floating voltage inverter switches for switched-capacitor filters", Arch. Elektr. Uebertr., 33, pp. 376-377, Sept. 1979.

P.E. Fleischer, K.R. Laker, "A family of active switched capacitor biquad building blocks", BSTJ, 58, No. 10, pp. 2235-2269, 1979.

A. Gersho and B. Gopinath, "Charge-routing networks", IEEE Trans. Circuits Syst., CAS-26, pp. 81-92, Feb. 1979.

P.R. Gray, R.W. Brodersen and D.A. Hodges, "MOS switchedcapacitor filters An overview", Proc. of the 1979 International Symposium on Circuits and Systems. Tokyo, Japan, pp. 905-908, 17-19 July, 1979.

P.R. Gray, D. Senderowicz, H. Ohara and B.W. Warren, “A single-chip NMOS dual channel filter for PCM telephony applications", Dig. Tech. Papers Int. Solid State Circuits Conf., Philadelphia, PA, pp. 26-27, Feb. 1979.

P.R. Gray, D. Senderowicz, H. O'Hara and B.M. Warren, “A single-chip NMOS dual channel filter for PCM telephony applications", IEEE J. Solid State Circuits, SC-14, pp. 981-991, Dec. 1979.

R. Gregorian, Y.A. Haque, R. Mao, R. Blasco and W.E. Nicholson, "CMOS switched capacitor filter for a two-chip PCM voice coder" IEEE Int. Solid State Circuits Conf. Dig. Tech. Pap., pp. 28-29, Feb. 1979.

R. Gregorian and G.C. Temes, "Compensation for parasitic capacitances in switched capacitor filters", Record of the 13th Asilomar Conf. on Circuits and Systems, pp. 546-548, Nov. 1979.

R. Gregorian and W. Nicholson, "CMOS switched-capacitor filters for a PCM voice Codec", IEEE J. Solid State Circuits, SC-14, pp. 970-980, Dec. 1979.

R. Gregorian and G.C. Temes, "Self-equalizing sample-andhold circuits" Elec. Letters, 15, pp. 367-368, June 21, 1979.

Y.A. Haque, R. Gregorian, D. Blasco, R. Mao and W. Nicholson, "A two-chip PCM Codec with filters", IEEE J. Solid State Circuits, SC-24, No. 6, Dec. 1979.

D. Herbst, B. Hoefflinger, K. Schumacher, R. Schweer, A. Fettweis, K.-A. Owenier and J. Pandel, "MOS-Switchedcapacitor filters with reduced number of operational amplifiers", IEEE J. Solid State Circuits, SC-14, pp. 1010-1019, Dec. 1979. 
D. Herbst, B. Hoefflinger, K. Schumacher and R. Schweer, "Fuer hohe Integrationsgrade geeignete MOS-SchalterKondensator-Filter mit wenigen Operationsverstaerkern", NTG-Fachberichte, 68, pp. 94-98, Berlin, VDE, 1979.

D. Herbst, B. Hoefflinger, K. Schumacher, R. Schweer, A. Fettweis, K. Owenier and J. Pandel, "MOS switched capacitor filters", ISSCC Dig., pp. 74-75, 281-282, 1979.

C.R. Hewes, R.W. Brodersen and D.D. Buss, "Applications of CCD and switched capacitor filter technology", Proc. IEEE 67, pp. 1403-1415, Oct. 1979.

I.J. Hill, "Comment on "Alternative approach to the design of switched-capacitor filters", Electron. Lett., 15, No. 20, p. 650, Sept. 1979.

D.A. Hodges, P.R. Gray and R.W. Brodersen, 'Enhancing MOS/LSI's role in analog design", IEEE Spectrum, 15, pp. 24-32, Feb. 1979.

M.E. Hoff, J. Huggins, Jr. and B.M. Warren, "An NMOS telephone codec for transmission and switching applications" IEEE J. Solid State Circuits, SC-14, pp. 47-53, Feb. 1979.

B.J. Hosticka, "Novel dynamic CMOS amplifier for switched capacitor integrators", Electron. Letters, 15, pp. 532-533, Aug. 16, 1979.

B.J. Hosticka, "Dynamic amplifiers in CMOS technology", Electron. Letters, 15, pp. 819-820, 1979.

B.J. Hosticka and G.S. Moschytz, "Practical design of switched capacitor networks for integrated circuit implementation", Inst. Elec. Eng. Electronic Circuits Syst., 3, pp. 76-88, March 1979.

B.J. Hosticka and G.S. Moschytz, "FDNR transformation for switched capacitor networks" Proc. 1979 Int. Symp. Circuits and Systems, pp. 766-769, Tokyo, Japan, July 1979.

J. Huggins, M.E. Hoff and B.M. Warren, "An NMOS PCM codec for voice" IEEE J. Solid State Circuits, SC-13, Feb. 1979.

G.M. Jacobs, G.F. Landsburg, B.J. White and D.A. Hodges, "Touch-tone decoder chip mates analog filters with digital logic", Electron., 52, pp. 105-112, Feb. 15, 1979.

M. Kakuishi, S. Kato and A. Ito, "Some studies on switched capacitor filters", Proc. of the 1979 International Symposium on Circuits and Systems, Tokyo, Japan, pp. 760-761, 17-19 July 1979.

A. Knob and R. Dessoulavy, "Two-port representation of basic switched capacitor structures by analog elements", Proc. of the 4th Int. Symp. on Network Theory, Ljubljana, pp. 419-423, Sept. 4-7, 1979.

Y.L. Kuo, M.L. Liou and J.W. Kasinskas, "Equivalent circuit approach to the computer aided analysis of switched capacitor circuits", IEEE Trans. Circuits and Systems, CAS-26, No. 9, pp. 708-714, Sept. 1979.

C.F. Kurth and G.S. Moschytz, "Two port analysis of switched capacitor networks using four-port equivalent circuits in the z-domain", IEEE Trans. Circuits Syst., CAS-26, pp. 166-180, March 1979.

C.F. Kurth and G.S. Moschytz, "Nodal analysis of switched capacitor networks", IEEE Trans. Circuits Syst., CAS-26, pp. 93-105, Feb. 1979.
K.R. Laker, "Equivalent circuits for the analysis and synthesis of switched capacitor networks", B.S.T.J., 58, pp. 727-767, March 1979.

M.S. Lee, "Switched capacitor filters using floating-inductance simulation circuits", Electronics Letters, pp. 644-645, Sept. 27, 1979.

C.F. Lee and W.K. Jenkins, "Computer aided analysis of switched capacitors filters", Conference Record of the 13th Asilomar Conference on Circuits, Systems and Computers, Pacific Grove, USA, pp. 552-555, 5-7 Nov. 1979.

M.L. Liou and Y.L. Kuo, "Exact analysis of switched capacitor circuits with arbitrary inputs", IEEE Trans. Circuits Syst., CAS-26, pp. 213-223, April 1979 - See also Proc. ISCAS, pp. $745-747,1979$.

E. Lueder, "Minimizing the manufacturing sensitivity of fully integrated filters", $A E U 79,33$, pp. 343-346, 1979.

K. Martin and A.S. Sedra, "Strays-insensitive switched capacitor filters based on the bilinear z-transform", Electron. Letters, 15, pp. 365-366, June 1979.

K. Martin and A.S. Sedra, "Some applications of the switched capacitor technique in conjunction with phase-lock loops", Proceedings of the 1979 International Symposium on Circuits and Systems. Tokyo, Japan, pp. 770-1, 17-19 July, 1979.

K. Martin, "Improved circuits for the realization of switched capacitor filters", Proceedings of the 1979 International Symposium on Circuits and Systems, Tokyo, Japan, pp. 756-759, 17-19 July, 1979.

G. Martinelli and M. Salerno, "Simplified analysis of passive switched capacitor circuits", Alta Freq., Italy, 48, No. 11, pp. 675-680, Nov. 1979.

J.A. Nossek, "Switched capacitor filters: a comparison and some experimental results", Frequenz, 33, pp. 219-222, July/Aug 1979.

H. O'Hara, S. Sando, P. Gray and D. Senderowicz, "First monolithic PCM filter cuts cost of telecomm systems", Electron. Design, 27, pp. 130-135, 12 April, 1979.

K.B. Ohri and M.J. Callahan, Jr., "Integrated PCM codec", IEEE J. Solid State Circuits, SC-14, pp. 38-46, Feb. 1979.

B.G. Pain, "Alternative approach to the design of switched capacitor filters", Electron. Lett., 15, No. 14, pp. 438-439, July 5, 1979.

J. Pandel, "Sequential voltage-inversion principle for switched capacitor filters", Electron. Lett., 15, pp. 399-400, June 21, 1979.

J.G. Peterson, "A monolithic fully parallel, 8b A/D converter", ISSCC Dig. Tech. Papers, pp. 128-129, Feb. 1979.

E. Sanchez-Sinencio and J.L. Gomez-Osono, "Switched capacitor simulation of grounded inductors using operational amplifier pole", Electron. Lett., 15, pp. 169-170, March 15, 1979.

E. Sanchez-Sinencio, P.E. Allen, I.I. Arreola and J.L. Gomez, "A direct design approach for analog sampled data filters", Record of the 13th Asilomar Conference on Circuits and Systems, pp. 538-541, Nov. 1979. 
R. Schweer, J. Pandel and D. Herbst, "MOS Schalter-Kondensator-Filter mit Spannungsumkehrschaltern", NachrichtenElektronik, 10, pp. 321-326, Oct. 1979.

E. Simonyi and A. Heszberger, "Design of recursive CCD and multiple - loop feedback switched capacitor filters using wave matrix techniques", Proceedings of the 1979 International Symposium on Circuits and Systems, Tokyo, Japan, pp. 762-765, 17-19 July, 1979.

G.C. Temes and R. Gregorian, "Compensation for parasitic capacitances in switched capacitor filters", Electron. Lett., 15, pp. 337-379, June 21, 1979.

G.C. Temes and M. Jahanbegloo, "Switched capacitor circuits bilinearly equivalent to floating inductor or FDNR", Electron. Lett., 15, pp. 87-88, February 1979.

Y.P. Tsividis, "Analytical and experimental evaluation of a switched capacitor filter and remarks on the resistor/switched capacitor correspondence", IEEE Trans. Circuits Syst., CAS-26, pp. 140-144, Feb. 1979.

Y.P. Tsividis, "Analysis of switched capacitive networks", IEEE Proc. Int. Symp. Circuits and Systems, Tokyo, pp. 752-755, July 1979 .

Y.P. Tsividis, "Analysis of switched capacitive networks", IEEE Trans. on Circuits and Systems, CAS-26, pp. 935-947, Nov. 1979.

Y.P. Tsividis and D.L. Fraser, Jr., "A process insensitive NMOS operational amplifier", Digest of the 1979 ISSCC, pp. 188-189, February 1979.

H. Ueda and T. Aoyama, "On synthesis and analysis of IIR sampled - data filters using switched capacitors", Paper of Technical Group on Communications Systems, IECE Japan, TGCST 78-121, pp. 19-24, Jan. 1979 (in Japanese).

P. Van Dooren, "The computation of Kronecker's canonical form of a singular pencil", Linear Algebra Appl., 27, pp. $103-141,1979$.

R. Van de Plassche, "A 7b A/D converter", ISSCC Dig. Tech. Papers, pp. 132-133, Feb. 1979.

T.R. Viswanathan, S.M. Faruque, K. Singhal and J. Vlach, "MOS switched capacitor amplifiers", Electron. Lett., pp. 634-635, 1979.

T.R. Viswanathan, J. Vlach and K. Singhal, "Switched capacitor transconductance elements and gyrators", Electron. Lett., 15, pp. 317-318, 1979.

E. Vittoz, "Micropower switched capacitor oscillator", IEEE J. Solid State Circuits, SC-14, pp. 622-624, June 1979.

B. White, G. Jacobs and G. Landsburg, "A monolithic dualtone multifrequency reciever", IEEE J. Solid State Circuits, SC-14, pp. 991-997, Dec. 1979.

B.J. White, G.M. Jacobs and G.F. Landsburg, "A monolithic dual-tone multifrequency receiver", Dig. Tech. Papers, 1979 Int. Solid State Circuits Conf., Philadelphia, PA, pp. 36-37, Feb. 1979.

I.A. Young and D.A. Hodges, "MOS switched capacitor analog sampled - data direct-form recursive filters", IEEE $J$. Solid State Circuits, SC-14, No. 6, pp. 1020-1033, Dec. 1979.
1980

D.J. Allstot and K.S. Tan, "A switched capacitor N-path filter", Proc. ISCAS, pp. 313-316, Houston 1980.

W.C. Black, Jr., D.J. Allstot, S. Patel and J. Weiser, "CMOS PCM channel filter", ISSCC Dig. of Tech. Papers, pp. 84-85, Feb. 1980 - See also IEEE Journal Solid State Circuits, SC-15, pp. 929-938, Dec. 1980.

M. Bon and A. Konczykowska, "A topological analysis program for switched capacitor networks with symbolic capacitors and switching functions", Proc. ECCTD-80, Warsaw, pp. 159-164, 1980.

P.W. Bosshart, "Architectures for analog LSI implementations of speech processing systems", Ph.D. Thesis, Massachusetts Inst. of Technol., Cambridge, May 1980.

P.W. Bosshart, "A multiplexed switched capacitor filter bank", ISSCC Dig. Tech. Papers, San Francisco, CA, pp. 92-93, Feb. 1980 - See also IEEE Journal Solid State Circuits, SC-15, pp. 939-945, Dec. 1980.

F. Brglez, "SCOP - A switched capacitor optimization program", Proc. IEEE Symp. Circuits and Systems, Houston, pp. 985-988, April 1980

R.W. Brodersen, P. Hurst and D.I. Allstot, "Switched capacitor applications in Speech Processing", IEEE Proc. ISCAS, Houston, pp. 732-737, April 1980.

U.W. Brugger and B.J. Hosticka, "A prewarping scheme for the design of switched capacitor filters", IEEE Proc. ISCAS, Houston, pp. 317-320, April 1980.

U.W. Brugger, E. Hoekenek, B.J. Hosticka and G.S. Moschytz, "Amplifier multiplexing in switched capacitor filters", Proc. ECCTD, pp. 354-359, Warsaw, 1980.

U.W. Brugger, "Switched capacitor filter design for communication systems", Proc. ECCTD-80, pp. 73-84, Warsaw, 1980.

L.T. Bruton, "Circuit theory concepts applied to the design of 1D and 2D digital, RC-active and switched capacitor filters", Proc. of the 1980 IEEE International Symposium on Circuits and Systems, pp. 994-1000, Houston, Tx, USA, 28-30 April, 1980.

T.C. Choi and R.W. Brodersen, "Considerations for high frequency switched capacitor ladder filters", IEEE Trans. on Circuits and Systems, CAS-27, pp. 545-552, June 1980.

P. Christiansen and O. Manck, "Simulation of SC-filters", Proc. of ESSCIRC 80, Grenoble, Sept. 22-25, 1980.

D.B. Cox and L.T. Lin, "A realtime programmable switched capacitor filter", ISSCC Dig. Tech. Papers, pp. 94-95, Feb. 1980.

D.C. Cox, L.T. Lin, R.S. Florek and H.-F. Tseng, "A realtime programmable switched capacitor filter", IEEE Journal Solid State Circuits, SC-15, pp. 972-977, Dec. 1980 - See also Digest of ISSCC, pp. 94-95, 1980.

A.M. Davis and R.R. Buss, "Using the R5610 quad filter array", Electron. Prod. Des., (GB), 1, No. 3, pp. 40-44, June 1980.

R.D. Davis and T.N. Trick, "Optimum design of low-pass switched capacitor ladder filters", IEEE Trans. on Circuits and Systems, CAS-27, pp. 522-527, June 1980. 
H. De Man, J. Rabaey, G. Arnout and J. Vandewalle, "DIANA as a mixed - mode simulator for MOSLSI sampleddata circuits", Proc. IEEE Symp. Circuits and Systems, pp. 435-438, Houston, April 1980.

H. De Man, "Mixed-mode simulation techniques and their implementation in DIANA", NATO ASI on Computer aids for VLSI circuits, Urbino, July 1980.

H. De Man, J. Rabaey, G. Arnout and J. Vandewalle, "Practical implementation of a general computer aided design technique for switched capacitor circuits", IEEE J. of Solid State Circuits, SC-15, pp. 190-200, April 1980.

R. Dessoulavy et al., "A synchronous switched capacitor filter", IEEE J. Solid State Circuits, SC-15, pp. 301-305, June 1980.

E.I. El-Masry, "Strays-insensitive active switched capacitor biquad", Electronics Letters, 16, pp. 480-481, June 1980.

C.S. Fan, R. Gregorian, G.C. Temes and M. Zommorodi, "Switched capacitor filters using unit-gain buffers", IEEE Proc. ISCAS, pp. 334-337, Houston, April, 1980.

S.C. Fang, Y.P. Tsividis, "Modified nodal analysis with improved numerical methods for switched capacitive networks", Proc. of ISCAS 80, Houston, pp. 977-980.

A. Fettweis, D. Herbst, B. Hoefflinger, J. Pandel and R. Schweer, "MOS switched capacitor filters using voltage inverter switches", IEEE Trans. Circuit Syst., CAS-27, pp. 527-538, June 1980.

A. Fettweis and A. Khalil, "Optimal anti-aliasing and conversion filters", IEEE Trans. on Circuits and Systems, CAS-27, pp. 559-566, June 1980.

T. Fjallbrant and S. Eriksson, "A time-shared resistor concept applied to active RC and SC integrator filters derived from flowgraph representations of passive counterparts", Proc. of the 1980 IEEE International Symposium on Circuits and Systems, pp. 79-82, Houston, TX, USA, 28-30 April, 1980.

P.E. Fleischer, K.R. Laker, D.G. Marsch, J.P. Ballantyne, A.A. Yiannoulos and D.L. Fraser, Jr., "An NMOS analog building block for telecommunication applications", IEEE Trans. Circuits and Systems, CAS-27, No. 6, pp. 552-559, June 1980.

D. Fullagar, "CMOS cornes of age", Spectrum, 17, pp. 24-27, Dec. 1980.

G. Girolami, "Development of an electronically switched high pass filter", Electron. and Appl. Ind., France, No. 284, pp. 45-47, 1 May 1980 .

P.R. Gray, D.A. Hodges and R.W. Brodersen (eds.), Analog MOS Integrated Circuits, IEEE Press, New York, 1980.

R. Gregorian and W.E. Nicholson, Jr., "MOS sampled-data high-pass filters using switched capacitor integrators", Microelectron. J., 11, No. 2, p. 22-25, March-April 1980.

R. Gregorian, "Filtering techniques with switched capacitor circuits", Microelectronics Journal, 11, No. 2, pp. 13-21, March-April, 1980.

R. Gregorian and W.A. Nicholson, "A switched capacitor high-pass filter", IEEE Trans. on Circuits and Systems, CAS-27, pp. 226-229, March 1980.
R. Gregorian, "Switched capacitor filter design using cascaded sections", IEEE Trans. on Circuits and Systems, CAS-27, pp. 515-521, June 1980.

R. Gregorian and W.E. Nicholson, "CMOS Switched capacitor filters for a PCM voice CODEC”, IEEE J. Solid State Circuits, 14, pp. 970-980, Dec. 1980.

R. Gregorian and W.E. Nicholson, "Switched capacitor decimation and interpolation circuits", IEEE Trans. Circuits and Systems, CAS-27, No. 6, pp. 509-514, June 1980.

R. Gregorian and W.E. Nicholson Jr., "Monolithic CMOS filters for a PCM voice CODEC", ICC 80, 1980 International Conference on Communications, Seattle, WA, USA, pp. 30.3/1-5, 8-12 June 1980.

H. Gutsche, "On the analysis of switched capacitor circuits including parasitic elements", Proc. of ISCAS 80, Houston, pp. 973-976, April 1980.

I. Haritantis and J. Pandel, "Wave switched capacitor filters", Proc. ECCTD Conf., Warsaw, pp. 366-371, 1980.

D. Herbst and B.I. Hosticka, "Novel bottom-plate strayintensitive voltage inverter switch", Electron. Lett., 16, pp. 636-637, July 1980 .

E. Hoekenek and G.S. Moschytz, "Analysis of multiphase switched capacitor networks using the indefinite admittance matrix", IEE Proc., 127, Pt. G, pp. 226-241, 1980.

E. Hoekenek and G.S. Moschytz, "Analysis of general switched capacitor networks using indefinite admittance matrix", IEE Proc., 127, Pt. G, No. 1, pp. 21-33, Feb. 1980.

B.J. Hosticka and G.S. Moschytz, "Switched capacitor filters using FDNR-like super capacitances", IEEE Trans. Circuits and Systems, CAS-27, No. 6, pp. 569-573, June 1980.

T. Hui and D. Allstot, "MOS switched capacitor high pass/ notch ladder filters", Proc. ISCAS 1980, Houston, pp. 309-312, 1980.

A. Iawata, S. Hattori, K. Uchimura, H. Shimizu and K. Ogasawara, "PCM CODEC and filter system", 1980 IEEE International Solid State Circuits Conference, Digest of Technical Papers, Philadelphia, PA, USA, pp. 178-179, 13-15, Feb. 1980.

T. Inoue and F. Ueno, "A new switched capacitor unitycoupled transformer simulation circuit and its theoretical analysis", Trans. Inst. Electron. and Comm. Eng. Jpn, Sect. E Japan, E63, No. 6, pp. 460, June 1980.

T. Inoue and F. Ueno, "Switched capacitor immitance converters using a single operational amplifier", Electronics Letters, 16, pp. 770-771, Sept. 1980.

T. Inoue and F. Ueno, "New switched capacitor immitance converter using operational amplifier leapfrog structure", Electronics Lett., 16, pp. 266-267, March 1980.

K. Inui, Y. Jyo and S. Minamoto, "A sensitivity analysis of switched capacitor filters", Paper of Technical Groupe on Circuits and Systems, IECE Japan, TGCAS 79-167, pp. 25-28, March 1980 (in Japanese). 
Y. Ito, T. Maekawa, T. Yamamoto and K. Tanikawa, "CCD/ CMOS transversal filter using switched capacitor technique for signal detection", Electronics Letters, 16, pp. 724-725, Sept. 1980.

A. Knob, Cl. Gobet and F. Krummenacher, "Sixth order switched capacitor leapfrog lowpass filter achieving the bilinear z-transform", Proc. ECCTD Conf., Warsaw, pp. 378-383, 1980.

A. Knob, "Novel strays insensitive switched capacitor integrator realising the bilinear z-transform", Electronics Letters, 16, pp. 173-174, Feb. 1980.

A. Konczykowska and M. Bon, "Topological analysis of switched capacitor network", Electronics Letters, 16, No. 3, pp. 89-90, Jan. 31, 1980.

K. Kraus, "Designing with solid-state analogue switches N-path filter applications", Electron. Ind., 6, No. 5, pp. 31-33, May 1980.

K. Krummenacher and J.L. Zufferey, "High-gain CMOS cascode operational amplifier", Electronics Letters, 16, pp. 232-233, 1980.

C. Kurth, "Two port analysis of SC networks with continuous input signals", B.S.T.J., 59, No. 8, pp. 1297-1316, Oct. 1980.

K.R. Laker and P.E. Fleischer, "A general active switched capacitor biquad topology for precision filters", IEEE Proc. ISCAS, Houston, pp. 304-308, April 1980.

E. Langer, "Coil-less filter-from hybrid technology to monolith", Elektron. Ind., 11, No. 3, pp. 11-14, 1980.

J. Lau and I. Sewell, "Inclusion of amplifier finite gain and bandwidth in analysis of switched capacitor filters", Electronics Letters, 16, pp. 462-463, June 1980.

H.S. Lee and C. Chang, "Switched capacitor filters using the bilinear and LDI transformations", IEEE Proc. ISCAS, Houston, pp. 326-329, April 1980.

M.S. Lee and C. Chang, "Low-sensitivity switched capacitor ladder filters", IEEE Trans. on Circuits and Systems, CAS-27, pp. 475-480, June 1980.

M.S. Lee, "SC ladder filters", IEEE switched capacitor filter workshop, Palo Alto, CA, USA, Feb. 10-12, 1980.

M.S. Lee, "Parasitics-insensitive switched capacitor ladder filters", Electronics Letters, 16, pp. 472-473, June 1980.

M.S. Lee, "Improved circuit elements for switched capacitor ladder filters", Electronics Letters, 16, pp. 131-133, 1980.

M.S. Lee and C. Chang, "Switched capacitor filters using the LDI and bilinear transformations", Proc. Int. Symp. on Circuits and Syst., pp. 326-329, May 1980.

C.F. Lee and W.K. Jenkins, "Sensitivity analysis for switched capacitor circuits based on modified nodal analysis", Proc. Int. Conf. on Circuits and Computers, New York, pp. 855-858, 1980.

C.F. Lee and W.K. Jenkins, "Switched capacitor circuit analysis based on modified nodal analysis", Proc. of the 23rd Midwest Symposium on Circuits and Systems, Toledo, Ohio, August 1980.

M.K. Li, "Switched capacitor realization of C and D-sections", Electronics Letters, 16, pp. 603-604, July 1980.
M.K. Li, "Cascade synthesis of switched capacitor networks employing voltage inverter switches", Electronics Letters, 16, pp. 370-371, 1980.

A. Liberatore and S. Manetti, "Realization of non-reciprocal networks using switched capacitors", Proc. ISCAS, Houston, pp. 969-972, May 1980.

E. Lueder, "Switched capacitor filters insensitive to parasitics", Proc. ECCTD Conf., pp. 360-365, Warsaw, 1980., and $A E U$, 34, pp. 501-506, 1980.

F. Maloberti, F. Montecchi and V. Svelto, "An exact analysis of a switched capacitor circuit", Alta Freq., Italy, 49, No. 3 , pp. 213-217, May-June 1980.

S. Manetti and A. Liberatore, "Switched capacitor lowpass filter without active components", Electronics Letters, 16, pp. 883-885, Nov. 1980.

K. Martin, "Improved design techniques for switched capacitor filters", IEEE Trans. Circuits and Systems, CAS-24, No. 4, pp. 237-244, April 1980, "Correction to -", pp. 733, Aug. 1980.

K. Martin and A.S. Sedra, "Exact design of switched capacitor bandpass filters using coupled-biquad structures", IEEE Proc. ISCAS, Houston, pp. 338-341, April 1980 - See also IEEE Trans. Circuits and Systems, CAS-27, pp. 469-475, June 1980 .

K. Martin and A.S. Sedra, "Effects of the opamp finite gain and bandwidth on the performance of switched capacitor filters", IEEE Proc. ISCAS, Houston, pp. 321-325, April 1980.

K. Martin and A.S. Sedra, "Easing prefiltering requirements of SC filters", Electronics Letters, 16, No. 16, pp. 613-614, 31 July 1980

G. Martinelli and M. Salerno, "Passive approach to switched capacitor circuits", Int. J. Circuit Theory and Applicat., 8, No. 3, pp. 325-335, 1980.

G. Martinelli and M. Salerno, "Switched capacitor filters with shifted resonators", Proc. of the 1980 IEEE International Symposium on Circuits and Systems, Houston, TX, USA, pp. 1001-3, 28-30 April 1980.

G. Martinelli and M. Salerno, "Parasitic effects in switched capacitor resonators", Proc. ECCTD Conf., Warsaw, pp. 437-442, 1980.

P. Moos and J. Kvasil, "Tunable switched capacitor band-pass filter with constant Q-factor", Proc. ECCTD Conf., Warsaw, pp. 425-430, 1980.

Y. Morikawa, E. Amada, T. Suzuki, "Development of an autobalance hybrid", Paper of Technical Group on Communication Systems, IECE Japan, TGCS 80-110, pp. 33-38, Aug. 1980 (in Japanese).

G.S. Moschytz and B.J. Hosticka, "Transmission matrix of switched capacitor ladder networks: application in activefilter design", IEE Proc., 127, Pt. G, No. 2, pp. 87-98, April 1980.

G. Mueller and G. Temes, "Simple method for analysis of a class of switched capacitor filters", Electronics Letters, 16, pp. 852-853, Oct. 1980.

J. Mulawka, "Switched capacitor network which uses threephase clock", Proc. ECCTD Conf., Warsaw, pp. 419-424, 1980. 
O. Nakamura and Y. Suzuki, "Application of switched capacitor for ADC and DAC", Paper of Technical Group on Semiconductors and Semiconductor devices, IECE Japan, TGSSD 80-66, pp. 61-68, Nov. 1980 (in Japanese).

J.A. Nossek and G.C. Temes, "Entwurf von SchalterKondensator-Filtern mit Hilfe der bilinearen Transformation", Arch. Elek. Uebertragung, 34, pp. 118-124, 1980.

I.A. Nossek and G.C. Temes, "Switched capacitor filter design using bilinear element modelling", IEEE Trans. on Circuits and Systems, CAS-27, pp. 481-491, June 1980 See also ISCAS Proc., pp. 330-330, Houston 1980.

J.A. Nossek and H. Weinrichter, "Equivalent circuits for switched capacitor networks including recharging devices", IEEE Trans. on Circuits and Systems, CAS-27, pp. 539-544, June 1980 - See also Proc. ISCAS, Houston, pp. 965-968, 1980 .

H. O'Hara, P. Gray, W. Baxter, C. Rahim and I. McCreary, "A precision low-power PCM channel filter with on chip power supply regulation", IEEE J. Solid State Circuits, SC-15, pp. 1005-1013, 1980.

H.J. Orchard and G.C. Temes, "Spectral analysis of switched capacitor filters designed using the bilinear z-transform", IEEE Trans. on Circuits and Systems, CAS-27, pp. 185-190, March 1980.

W. Reinecker, "Monolithic IC switched capacitor filters I", Elektronik, 29, No. 13, pp. 37-43, 26 .June 1980.

W. Reinecker, "Monolithic integrated filter with connected capacitors - II", Elektronik, 29, No. 14, 10 July 1980.

T. Ruebner-Petersen, "Realisation of oversampled switched capacitor filters", Proc. ECCTD Conf., Warsaw, pp. 431-436, 1980.

T. Ruebner-Petersen, "SC NET program for analysis of switched capacitor networks by means of poles and zeros", Proc. ISCAS 80, Houston, TX, pp. 989-993, April 1980.

E. Saad, "On the sensitivity and simplification of switched capacitor filters derived from digital structures", Proc. ECCTD Conf., Warsaw, pp. 372-377, 1980.

J.I. Sewell, "Analysis of active switched capacitor networks", Proc. of IEEE, 68, No. 2, pp. 292-293, Feb. 1980.

D.F. Sheahan, "Integrated filters for telecommunications, telephone equipment", ICC 80, 1980 International Conference on Communications, Seattle, USA, pp. 30.1/1-3, 8-12 June 1980.

G. Spahlinger, "Switched capacitor lowpasses with grounded simulated inductors", Proc. ECCTD Conf., Warsaw, pp. 414-418, 1980.

E.V. Sorensen, "Norator-nullator formulation of the network functions for switched capacitor circuits", Proc. ECCTD 80 Warsaw, pp. 153-158, 1980.

Y. Suzuki and O. Nakamura, "Application of switched capacitor to AGC circuit", Paper of Technical Group on Semiconductors and Semiconductor Devices, IECE Japan, TGSSD 80-65, pp. 53-60, Nov. 1980 (in Japanese).

G. Szentirmai and G.C. Temes, "Switched capacitor building blocks. Active filter design", IEEE Trans. Circuits and Systems, CAS-27, No. 6, pp. 492-501, 1980.
Z. Szmuda and W. Sienko, "Frequency transformations for the C-switched filter synthesis", Proc. ECCTD 80, Warsaw, pp. 171-177, 1980.

M. Tanaka and S. Mori, "Equation describing a passive switched capacitor network", Trans. IECE 1980/5, 63-A, pp. 309-315, May 1980 (in Japanese).

M. Tanaka and S. Mori, "Equation describing an active switched capacitor network", Trans. IECE 1980/11, 63-A, pp. 761-768, Nov. 1980 (in Japanese).

H. Tanaka, M. Yamasawa, S. Kato, A. Itoh, M. Takahashi, M. Ohhata and A. Iwata and S. Hattori, "PCM coder and decoder IC's with switched capacitor filters", 1980 IEEE International Solid State Circuits Conference Digest Technical Papers, Philadelphia, pp. 172-173, Feb. 13-15, 1980.

G.C. Temes, "Finite amplifier gain and bandwidth effects in switched capacitor filters", IEEE J. Solid State Circuits, SC-15, No. 3, pp. 358-361, June 1980.

G.C. Temes and M.B. Ghaderi, "Bilinear switched capacitor ladder filter with reduced number of amplifiers", Electronics Letters, 16, pp. 412, May 1980.

H. Toda, K. Ohmura and H. Ueda, "Synthesis and analysis programs for SCF-Based on LCR ladder filers", Paper of Technical Group on Circuits and Systems, IECE Japan, TGCAS 79-164, pp. 13-16, March 1980 (in Japanese)

J. Tsantes, "Monolithic active filters come on strong: hybrid and module technologies mature", $E D N$, pp. 49-64, March 20, 1980.

Y. Tsividis, "Basic properties of switched capacitive networks", Proc. ECCTD 80, Warsaw, 20 pages.

J. Vandewalle, H. De Man and J. Rabaey, "A unified theory for the computer aided analysis of general switched capacitor networks", Proc. ECCTD 80 Conference, Warsaw, Poland, pp. 147-152, Sept. 1980.

I. Vandewalle, H. De Man and J. Rabaey, "The adjoint switched capacitor network and its applications", Proc. IEEE Symp. Circuits and Systems, Houston, pp. 1031-1034, April 1980.

T.R. Viswanathan, S.M. Faruque, K. Singhal and J. Vlach, "Switched capacitor transconductance and related building blocks", IEEE Trans. on Circuits and Systems, CAS-27, pp. 502-508, June 1980. - See also Proc. ISCAS 1980, Houston, pp. 981-984.

T.R. Viswanathan and T.L. Viswanathan, "Increasing the clock-frequency of switched capacitor filters", Electronics Letters, 16, pp. 316-317, 1980.

E. Vittoz and F. Krummenacher, "Micropower SC filters in Si-gate technology", 1980 European Conference on Circuit Theory and Design, Warsaw, Vol. 1, pp. 61-73, Sept. 2-5, 1980.

D.C. Von Gruenigen, U.W. Brugger and B.I. Hosticka, "Bottom-plate stray-insensitive bilinear switched capacitor integrators", Electronics Letters, 16, pp. 25-26, 1980.

D.C. Von Gruenigen, U.W. Brugger and B.J. Hosticka, "Bottom-plate stray-insensitive bilinear switched capacitor integrators", Electronics Letters, 16, No. 1, pp. 25-26, 3rd Jan. 1980. 
D.C. Von Gruenigen and U.W. Brugger, "Closed-form analysis of nonideal switched capacitor networks", Proc. of ECCTD 80, Warsaw, pp. 165-170, 1980.

D. Von Gruenignen, "Verfahren zur Analyse von SchalterKondensator-Netzwerken", AGEN Mitteilungen, No. 29, 1980.

D.C. Von Gruenigen and U.W. Brugger, "Closed form analysis of nonideal switched capacitor networks", Proc. ECCTD Conference, Warsaw, pp. 165-170, 1980.

D.C. Von Gruenigen, U.W. Brugger and G.S. Moschytz, "Novel stray-insensitive switched capacitor integrator", Electronics Letters, 16, 395-397, 1980.

G.P. Weckler, "User programmable switched capacitor filters", Digest of Tech. Papers, ESSCIRC 80, Grenoble, pp. 321-323, Sept. 1980.

H. Weinrichter and J.A. Nossek, "Switched capacitor filters: a comparison of the basic design principles", Proc. ECCTD 80, Warsaw, pp. 17-28, 1980.

I.A. Young, D.B. Hildebrand and C.B. Johnson, "A low power NMOS transmit/receive IC filter for PCM telephony", ISSCC Dig. of Tech. Papers, pp. 184-185, Feb. 1980.

I. Young, D. Hildebrand and C.B. Johnson, "A low power NMOS transmit/receive IC filter for PCM telephony", New Electron., 13, No. 9, pp, 50, 29 April 1980.

I. Young, "A low power NMOS transmit/receive IC filter for PCM telephony", IEEE Journal of Solid State Circuits, SC-15, pp. 997-1005, 1980.

\section{1}

B.K. Ahuja and D.G. Marsch, "A single-chip CMOS PCM CODEC with filters", Digest Int. Solid State Circuits Conf., pp. 242-243, 1981.

N. Attaie and E.I. El-Masry, "Synthesis of switched capacitor filters in the multiple-input follow the leader feedback topology", IEEE ISCAS Conference, pp. 175-178, Chicago 1981.

R. Beck, "A general modulation method for the reconstruction of periodic nonuniformity sampled bandwidth limited signals", IEEE ISCAS Conference, pp. 162-165, Chicago 1981.

U.W. Brugger, D.C. Von Gruenigen and G.S. Moschytz, "A step-by-step procedure for the design of cascaded switched capacitor filters", to be published.

T. Claasen and W. Mecklenbrauker, "On stationary linear time varying systems", Proc. ISCAS, pp. 443-446, Chicago, 1981.

R.D. Davis, "A derivation of the switched capacitor adjoint network based on a modified Tellegen's theorem", IEEE ISCAS Conference, pp. 872-975, Chicago 1981.

R.D. Davis, "Distortion analysis of switched capacitor filters", IEEE ISCAS Conference, pp. 876-879, Chicago 1981.

E.I. El-Masry, "Design of switched capacitor filters in the biquadratic state-space form", IEEE ISCAS Conference, pp. 179-182, Chicago 1981 .
A. Fettweis, "Switched capacitor filters: From early ideas to present possibilities", IEEE ISCAS Conference, pp 414-417, Chicago 1981.

T. Fjallbrant, "Analysis of some time-sharing methods in SC - filter design", IEEE ISCAS Conference, pp. 187, Chicago 1981.

P.E. Fleischer, A. Ganesan and K.R. Laker, "Effects of finite op-amp gain and bandwidth on switched capacitor filers", IEEE ISCAS Conference, pp. 41, Chicago 1981.

B. Furrer and W. Guggenbuhl, "Noise analysis sampled-data circuits", IEEE ISCAS Conference, pp. 860-863, Chicago 1981.

R.L. Geiger and E. Sanchez-Sinencio, "Operational amplifier gain-bandwidth product effects on the performance of switched capacitor networks", IEEE ISCAS Conference, pp. 37-40, Chicago 1981.

M.S. Ghausi and K.R. Laker, Modern Filter Design: Active $R C$ and Switched Capacitor, Prentice Hall, Englewood Cliffs, 1981.

C.A. Gobet and A. Knob, "Noise analysis of switched capacitor networks", IEEE ISCAS Conf., pp. 856-859, Chicago 1981.

P.R. Gray, R.W. Brodersen, D.A. Hodges, T. Choi, R. Kaneshiro and K.C. Hsieh, "Some practical aspects of switched capacitor filter design", IEEE ISCAS Conference, pp. 419-422, Chicago 1981.

R. Gregorian and G. Amir, "An integrated single chip, switched capacitor, speech synthesizer", IEEE ISCAS Conference, pp. 733-736, Chicago 1981.

M. Hasler, "Stray capacitance insensitive switched capacitor filters", IEEE ISCAS Conference, pp. 42-45, Chicago 1981.

K.-C. Hsieh and P.R. Gray, "A low noise chapper stabilized differential switched capacitor filtering technique", Digest Int. Solid State Circuits Conf., pp. 128-129, 1981.

A. Iawata, K. Kikuchi, K. Uchimura, A. Morino and M. Nakajima, "A single chip CMOS CODEC with switched capacitor filters", Digest. Int. Solid State Circuits Conf., pp. 244-245, 1981.

A. Iwata, K. Uchimura, S. Hattori, H. Shimizu and K. Ogasawara, "Low power PCM codec and filter system", IEEE J. of Solid State Circuits 1981.

T. Kaneko, H. Kikuchi and A. Iwata, "A construction of multiplexed SCF", 1981 National Convention Record of the Institute of Electronics and Communications Engineers of Japan (in Japanese).

A. Khalil and J. Pandel, "Interpolation circuits as a test-aid for switched capacitor filters and digital filters", $A E U, 35$, No. 4, 1981.

A. Knob and R. Dessoulavy, "Analysis of switched capacitor networks in the frequency domain using continuous-time two-port equivalents", IEEE Trans. on Circuits and Systems, CAS-28, pp. 947-953. Oct. 1981.

F. Krummenacher, "High voltage gain CMOS OTA for micropower SC filters", Electronics Letters, 17, pp. 160-162, 1981.

K.R. Laker, P.E. Fleischer and A. Ganesan, "Parasitic insensitive switched capacitor biquads: A review", IEEE ISCAS Conference, pp. 423, Chicago 1981. 
M.S. Lee and C. Chang, "Switched capacitor filters using the LDI and bilinear transformations", IEEE Trans. on Circuits and Systems, CAS-28, pp. 265-270, April 1981.

M.S. Lee and C. Chang, G.C. Temes and M.B. Ghaderi, "Bilinear switched capacitor ladder filters - New results", IEEE ISCAS Conference, pp. 170-173, Chicago 1981.

M.S. Lee and C. Chang, "Exact synthesis of N-path switched capacitor filters", IEEE ISCAS Conference, pp. 166-169, Chicago 1981.

C.F. Lee and W.K. Jenkins, "Computer-aided analysis of switched capacitor filters", IEEE Trans. of Circuits and Systems CAS-28, pp. 681-692. July 1981.

P.M. Lin, "A hybrid matrix approach to switched capacitor circuit analysis", IEEE ISCAS Conference, pp. 880-883, Chicago 1981.

M.L. Liou, "A survey of Analysis Techniques for switched capacitor circuits", IEEE ISCAS Conference, pp. 418, Chicago 1981.

K. Martin and A. Sedra, "Effects of opamp finite gain and bandwidth on the performance of switched capacitor filters", IEEE Trans. on Circuits and Systems, CAS-28, pp. 822-829 Aug. 1981.

K. Martin and A.S. Sedra, "Switched capacitor building blocks for adaptive systems", IEEE ISCAS Conference, pp. 517-518, Chicago 1981.

J. Mavor, H. Reekie, P. Denyer and S. Scanlan, "Switched capacitor voltage-wave filter", Digest Int. Solid State Circuits Conf., pp. 122-123, 1981.-

L. McCready, A. Chowaniec, S. Watson, N. Mehta and D. Choi, "Monolithic formant-based parametric speech synthesizer", IEEE ISCAS Conference, pp. 986-988, Chicago 1981.

W.B. Mikhael and S.Tu, "Switched capacitor oscillators with linear frequency control", IEEE ISCAS Conference, pp. 188-191, Chicago 1981.

W.B. Mikhael and S. Tu, "Frequency compression employing switched capcitor oscillators (SCO's) and its application to FM detection", IEEE ISCAS Conference, pp. 58-61, Chicago 1981.

S.K. Mitra and P.P. Vaidyanathan, "Design of switched capacitor filters networks with minimum capacitor ratio and total capacitance", IEEE ISCAS Conference, pp. 326-333, Chicago 1981.

N. Mokhoff, "The march toward integrated telecommunication systems puts filters, codecs on same chip ... (technology '81)", Spectrum, 18, pp. 62-63, Jan. 1981.

G.S. Moschytz, "The analysis and design of biphase and multiphase SC networks", IEEE ISCAS Conference, pp. 513-516, Chicago 1981.

J.A. Nossek and H. Weinrichter, "Comments on "Switched capacitor filter design using the bilinear z-transform", IEEE Trans. on Circuits and Systems, CAS-28, pp. 78-81, Jan. 1981.
J. Pandel, "Switched capacitor elements for VIS-SC-filters with reduced influences of parasitic capacitances", $A E U$, 35, pp. 121-130, March 1981.

J. Rabaey, J. Vandewalle and H. De Man, "On the frequency domain analysis of switched capacitor networks including all parasitics", IEEE Symp. on Circuits and Syst., ISCAS 1981. Chicago, pp. 868-871.

S.O. Scanlan, "Analysis and synthesis of switched capacitor state variable filters", IEEE Trans. on Circuits and Systems, CAS-28, pp. 85-93, Feb. 1981.

R. Schauman, M.A. Soderstrand and K.R. Laker, Modern Active Filter Design, IEEE Press, 1981.

G. Spahlinger, "Simulierte Induktivitaeten mit geschalteten kondesatoren", $A E U E, 35$, pp. 53-55, Jan. 1981.

Y. Sun, "Direct analysis of time-varying continuous and discrete difference equations with applications to nonuniformly switched capacitor circuits", IEEE Trans. on Circuits and Systems, CAS-28, pp, 93-100, Feb. 1981.

T. Suzuki, H. Shirasu and N. Ohwada, "Recent work on switched capacitor circuits in Japan", IEEE ISCAS Conference, pp. 523-527, Chicago 1981.

H. Takatori, T. Suzuki, O. Yumoto, Y. Takasaki, M. Ogawa and K. Tomooka, "A switched capacitor sqf equalizer", 1981 National Convention Record of the Institute of Electronics and Communication Engineers of Japan (in Japanese).

E.A. Talkhan, "Compensation of the switched capacitor integrator", IEEE ISCAS Conference, pp. 33-36, Chicago 1981.

G.C. Temes, "Finite amplifier gain and bandwidth effects in switched capacitor filters", IEEE J. of Solid State Circuits.

G.C. Temes, M.B. Ghaderi and J. Nossek, "Switched capacitor pseudo N-path filters", IEEE ISCAS Conference, pp. 519-522, Chicago 1981.

Y.P. Tsividis, "Filter with transfer function coefficients dependent only on timing", IEEE ISCAS Conference, pp. 183-185, Chicago 1981.

J. Vandewalle, H. De Man and J. Rabaey, "The adjoint switched capacitor network and its application to frequency noise and sensitivity analysis", Circuit Theory and Applications, 9, pp. 77-88, 1981.

J. Vandewalle, L. Claesen and H. De Man, "Very efficient computer algorithms for direct frequency aliasing and sensitivity analysis of switched capacitor networks", ISCAS 81, Chicago, pp. 864-867.

J. Vandewalle, H. De Man and J. Rabaey, "Time, frequency and z-domain modified nodal analysis of switched capacitor networks", IEEE Trans. Circuits Syst., CAS-28, pp. 186-195, March 1981.

E. Wehrhahn, "Exact analysis of periodically switched linear networks",IEEE ISCAS Conference, pp. 884-887, Chicago 1981

K. Yamakido, T. Suzuki, M. Tanaka, K. Yasunari, J.

Sakaguchi and S. Hagiwara, "A single-chip CMOS filter CODEC", Digest Int. Solid State Circuits Conf., pp. 240-241, 1981. 

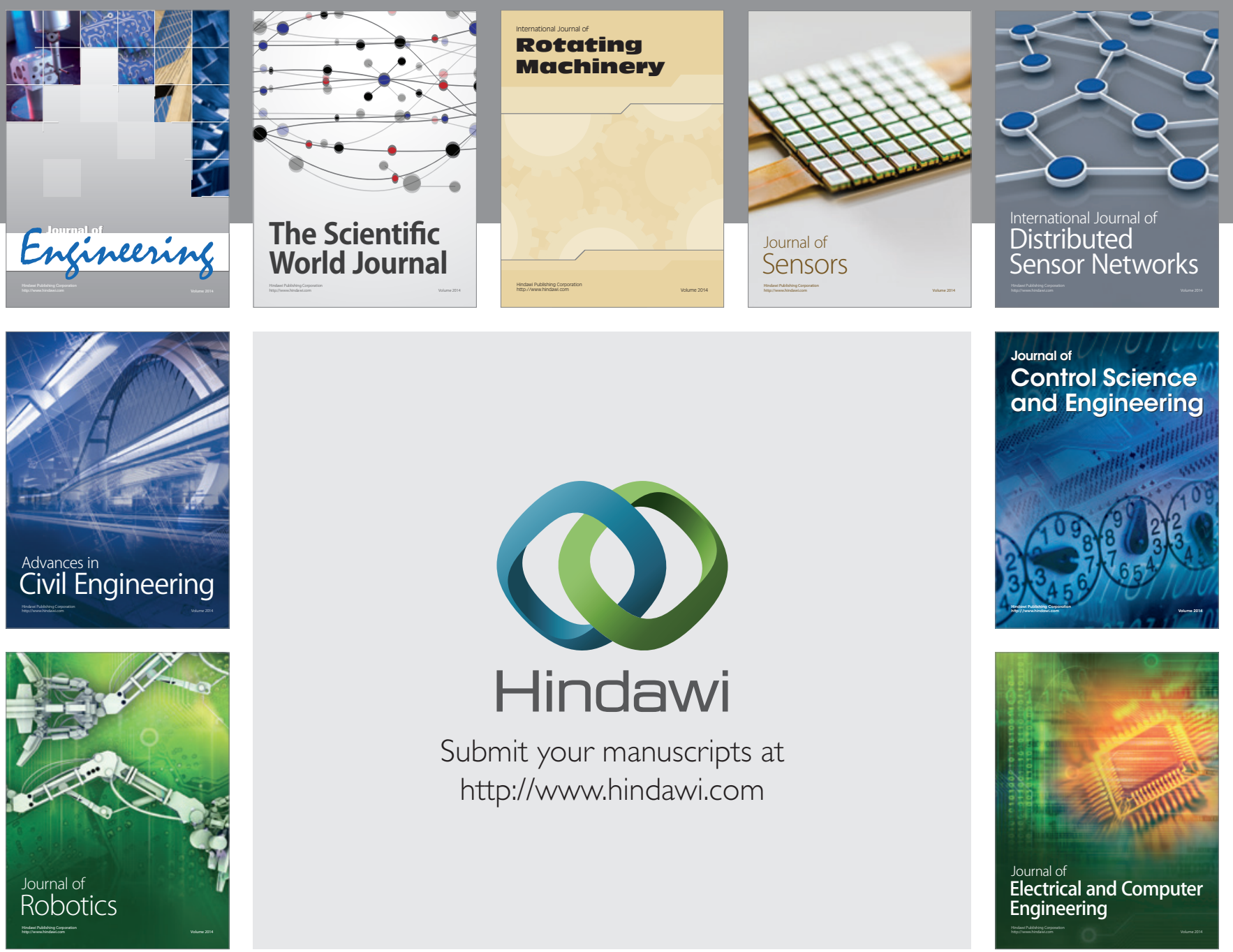

Submit your manuscripts at

http://www.hindawi.com
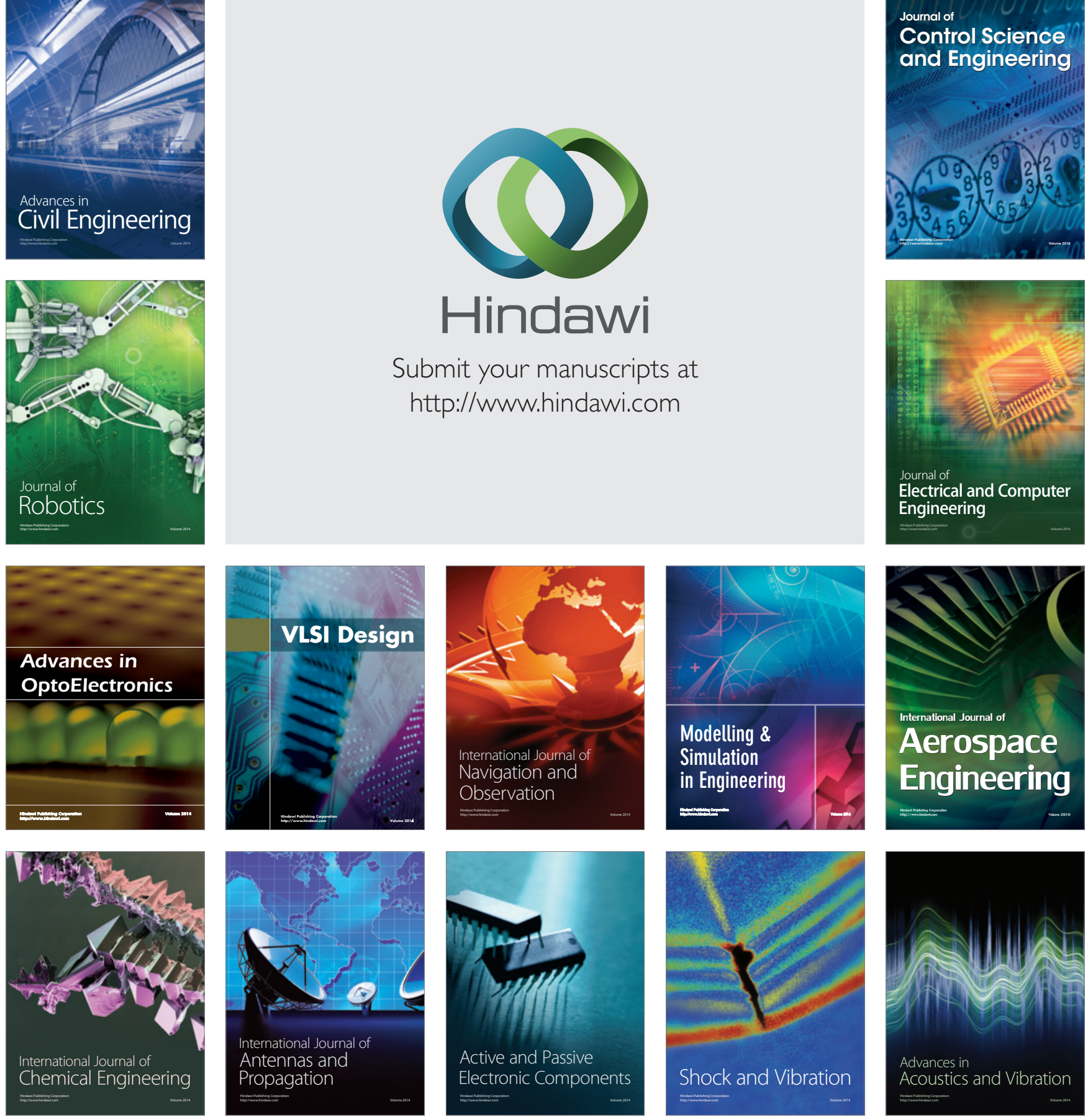